\title{
The nature and application of formational learning in the distance medium
}

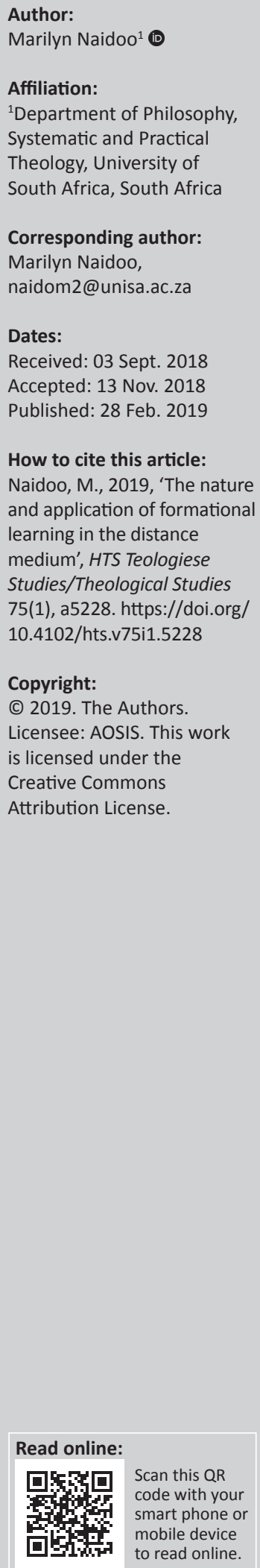

As theological education increasingly uses more flexible approaches to teaching and the number of distance education students increases, more attention needs to be placed on how formational education takes places in this environment. It is assumed that we cannot successfully address student formation in online learning contexts. However, with the advances in technology, the debate has moved on to exploring how theological education might adapt to new teaching and learning environments and use new pedagogies and technologies to prepare students for ministry. This article poses the question of how formational education is possible in the distance environment, considering the nature of formational education. In attempting an answer, the foundational dynamics of formation are unpacked using an analysis of the current literature together with highlighting the essential pedagogical factors of community, student support and faculty that are central to student formation. This article is of value as it highlights how formational education can be locally adapted within the distance mode.

\section{Background}

Distance education in the form of blended learning, hybrid courses or fully online is a key element of academic offerings in theological faculties at universities and bible colleges in South Africa. Theological institutions have long made use of distance learning to train church ministers because of the perceived benefits of potentially reduced costs through reaching a wide target audience. The need for distance theological education has grown for reasons of access - people living in remote or rural areas, especially older and practising pastors or lay leadership, those already in Christian ministry needing few credits to complete their qualification (Moodie 2008:50). In the last few decades, main-line denominations like the Anglicans and Methodists used the Theological Education by Extension College of Southern Africa, or even the University of South Africa for clergy training.

In our context, formational and vocational education takes place mostly in denominational theological training institutions rather than public universities; that focus on an academic model offering theology as an ecclesial discipline in the public sector. Having said that, some public universities, such as the North-West University with its open distance learning (ODL) unit, do provide distance education in a confessional mode. There are a growing number of smaller private theological colleges, for example, the Baptist Theological College, with about 80 contact students, which previously did not offer distance education, but now has over 300 distance learning students. Some have incorporated distance education opportunistically, as a convenient way to increase student enrolment in a competitive market, without the required capacity in ODL pedagogy. Nevertheless, the flexibility of learning provision, with the idea that students can succeed has made it a viable option for institutions. Given these potential benefits, especially with the move to a 'networked society' (Croft 2008), many churches also are engaging effectively with social media for ministry, together with its growing use by many church members.

Distance education curriculum and delivery has since changed from essentially correspondence courses to openness, with materials changing from being content-driven to becoming more student-centred, incorporating visual elements and multimedia such as YouTube, PowerPoint presentations, radio broadcasts, video conferencing and digital library resources. This trend towards student-centredness reflects international tendencies towards a more constructivist approach to ODL delivery (Bozkurt et al. 2015). In addition, academic staff have had to understand the nature of ODL and the rigours of teaching and learning through distance and mass education.

Note: OEH: The Online Educated Human: Teaching values, ethics, morals, faith and religion at a distance, sub-edited Ignatius Gous (University of South Africa). 
Within both academic and vocational modes of distance theological education, more needs to be done within the curriculum to promote the development of an integrated person. There must be a move away from controlled content delivery to the facilitation of the development of the student. Especially considering the type of student in training that is shaped by social and digital media and the negative impact of that, more needs to be done to nurture a new generation of leaders. As Hess states, 'eventually not only how we teach will change but the people preparing for religious leadership will be shaped by the technology itself' (2013:6). Formational education attends to the relational skills, integrity and character development of the professional found in other professions such as social work, psychology and the like:

No longer is education conceived in terms of function and role or the transmission and absorption of information - instead it has become an ontological activity in which the prime goal is human development. (Naidoo 2012:6)

Quality theological education extends beyond learning in the cognitive domain, even beyond the 'development of thinking skills, into the affective realm found in terms such as moral development, formation, spiritual maturity, character and other relatively intangible goals' (Patterson 1996:66). Hines et al. (2009:34). assert that church members view 'spiritual and relational skills as the highest priority for ministerial preparation.'

Theological educators question whether these skills and values can be nurtured in the distance environment when it is seen as a 'virtual fashion' in the marketplace. Some see distance education as 'distancing' the students in more significant ways than simply geographic distance. 'When the face-to-face personal dimension is removed in a distance or online course, concern remains whether the spiritual formation of students can be promoted' (Naidoo 2012:5). The challenge of facilitating spiritual formation in a climate that relies on 'text-based and largely asynchronous exchanges between physically isolated individuals' (Dawson 2004:77) raises concerns amongst Christian educators because the concept of learning in isolation and detachment runs counter to Christian nurturing and formation.

Indeed, questions regarding the capacity of distance and online programmes to provide a community of learning are a central reason for the hesitant acceptance of online learning in theological education. There have been many other objections to distance education:

\footnotetext{
... theological arguments - from theologies of community and embodiment and presence to the pedagogical argument 'this does not meet our standards for good or appropriate pedagogy', to the sociological argument 'there is a set of social dynamics that cannot be captured in this medium'. (Naidoo 2012:8)
}

Concerns about the legitimacy of the formational potential are valid, but the issue has moved on to 'the quality of content rather than the quality of delivery' (Killacky 2011:167). Scholars have now indicated that 'community can occur in an online context and that the social interaction of presence can replicate the face-to-face human interaction of traditional course offerings' (Brown 2012; Graham 2002; Nysse 2011; Ravoi \& Jordan 2004; Russel 1999). As distance learning has become a part of the landscape of theological education and adapts to technological and social change, the focus should be reframed and considered from the view of the positive gains that are found in virtual interaction (Delemarter 2014:140). Thus, the issue at hand is more about the quality of theological distance education and the ways in which distance courses can promote and support opportunities for formation.

It is important to note that when the intention towards formation education is not existent in educational institutions, as found in public universities in South Africa, it becomes difficult to structure and align formational initiatives. A national study on the intentionality of spiritual formation in contact theological education (Naidoo 2011) revealed that institutions have an awareness of the formational mandate to varying degrees; however, it is not clear how formational education is offered in the distance environment. The challenge in reflecting on local practice is that few theological colleges in South Africa have made use of online education because of the high cost of the infrastructure development. Added to this, academic staff tend to be overwhelmed with doing education rather than reflecting on what it is they do. This results in limited scholarship on different formation models in distance education or how theological training institutions should make proper use of information technologies for theological teaching. Given that institutions are driven by economic sustainability and pragmatics when it comes to distance education without fully considering the holistic ministerial preparation of students, this article will shed light on the fundamental dynamics that make for formational education in a distance environment by firstly explaining the unique features of formational education and its application in the distance space, and the essential pedagogical dynamics that must be in place for formation to take place.

\section{The alignment of formational education with distance education}

Since the prospect of incorporating distance formation education is a necessity with the advances of technology, this section will unpack the many commonalities between formational education and distance, like the focus on the individual in learning, a situated learning environment, transformative education focused on personal growth and a holistic focus for deep learning, to emphasis the possibilities that can exist for formational learning.

Firstly, formation is a 'model of learning in which faith, study and tradition inform one another, and thereby foster the development of the person' (Naidoo 2012:4). Because it is a process of becoming human (Smith 2009:70), there is a fluidness in the goal of achieving maturity supported by theological anthropology and developmental theory (Overend 2007:138). Words such as integration and wholeness 
offer an overarching intention for formative practices that integrates both cognitive and affective learning. Integrative practices encourage students to be self-critical and transparent to self and others about the theological commitments, personal qualities and spiritual integrity that they carry into their ministry. The self is examined and developed not simply in an instrumental understanding that focuses on the performance in ministry but on communicative dimension known as emotional intelligence, and ultimately becomes a search for meaning (Daloz 1987:62). While the formational process of growth and change happens within the individual, it is necessarily evidenced in relationship and in community. These practices identify behaviours that should show up in students' personal and religious work and be embodied in their very being as well as their doing (Hefner 2003).

Le Cornu (2003:18) suggests 'that the distance learning mode of education naturally lends itself to the formational mandate on account of its learner-centred pedagogical approach'. To conduct meaningful education is to begin where the students are. It involves 'student autonomy, instructor presence, and interactivity' (Pelz 2004:13). Student autonomy involves the ability to work with other students in learning, while the teacher 'maintains a supportive presence throughout, by guiding discussions, commenting on assignments and offering valuable feedback to students on a regular basis' (Pallof \& Pratt 2007:78). In this learner approach, the shift is from teaching information about the world towards a learning-based method through engagement with the world. In 'a world in which knowing is constantly changing, rarely fixed and deeply embedded in personal agency and experience, students have to learn by engagement - by doing, watching, experiencing' (Hess 2013:14). We live in a world where there is a huge body of knowledge and an inquiring mind is of essence in order to establish 'what we do not know' (Hess 2013:14). Technology represents a way of life where digital platforms become primary locations of communication and symbolic connections (Cloete 2015:144). It makes us think anew about the world and how we interact with it.

The philosophy of education used is based on constructivism that holds that learners actively construct meaning by interacting with their environments and by incorporating new information into their existing knowledge and hence building on prior knowledge and skills' (Njenga 2005:202). It is important to note that the limitless information available on the Internet may add value to the teaching and learning in class; however, in the online process, even though there is an abundance of information, 'the transformation of information into knowledge requires it to be adapted and contextualised to the learners' unique environments' (Martin \& Briggs 1986:13). This is because very few independent students can do this for themselves and it requires the expert help from a teacher 'to adapt and contextualise the information or facilitate the student's adaptation of such information' (Martin \& Briggs 1986:13). 'Content is organized then disseminated as the teacher helps students develop prior knowledge and familiarize themselves with each new learning experience' (Ascough 2002:23). Thus, careful attention needs to be made to the discussions and the scaffold design of the assignments. Learning happens when students move back and forth between learning and applying in ways that are immediate and seamless. This constructivist approach is in line with what Dan Aleshire refers to as the 'ecology of faith' in which different but complementary contexts shape students (in Lowe \& Lowe 2010:98). This idea was taken further by Lowe and Lowe (2010) who considered the entire social ecosystem on human development:

An ecological perspective on spiritual formation in Christian distance education permits us to consider the totality of contexts and settings in which students study, learn and grow. Rather than delimiting Christian development to physical faceto-face community, an ecological perspective broadens our perspective on multiple social environments ... to accomplish transformation. (p. 97)

Learning occurs in the social realm before it is internalised, showing the interdependency of learning with the sociocultural environment. 'This widening notion of community can impact the faculty's sense of its theological mission, as teachers engage the theological questions of communities at a distance' (Esselman 2005:160). Students' church work contexts must be incorporated into studies to supplement that formation that is already taking place in the church. This approach includes all the voices in the wisdom community; it 'frees the teaching and learning event to include all the members; it capitalizes on the personal and professional experiences that each bring to the conversation' (Delamarter 2014:141). To develop relationality, skills of discernment and communication in the distance medium is key and it can become a resource in face-to-face encounters, even in the evangelisation of others. Cannel suggests that 'an appropriate way to think of the involvement of the theological institution in ministerial education is not as preparatory but as developmental' (2006:38). In other words, the sustenance of the ministry profession is developed on regular and continuing education and this can be performed in the online mode where the individual is guided in reflection-on-practice.

The desired outcome of theological education is frequently expressed as transformation; it should have a life changing, transformative effect on students. Weinski states: 'It should be about coming to new and deeper understandings of Scripture and theological questions, training of ministry skills, spiritual growth, and character development' (2008:108). Personal and spiritual formations are terms used to describe the transformation desired in theological education. Both transformative learning theory and Christian formation are concerned with personal growth: the former in developing meaning perspective and the latter in Christian maturity (Reissner 1999). Transformative learning is a wellestablished education theory (Mezirow 1990) evidenced through changed decision-making and acting on new insights. The theory recognises that learning is more epistemic than cognitive, in that the learner does not merely know more, but becomes a different person (Mezirow 1990:62). 
For Mezirow, transformation is holistic, involving all aspects including the affective, cognitive and conative. Theological education can be transformative insofar as it intentionally encourages reflection and the reconsideration of one's own perspectives in the context of theological themes and this can happen in any medium in which a course of study is experienced, even distance.

The scope of formational education must go beyond a restrictive cognitive qualification to more integrated human development. Even though knowledge is the most appropriate for easy delivery in the distance model, there is increasing evidence that there is potential for skills training online (Elias 2006) with the use of YouTube videos for discussion in pastoral counselling classroom and tutoring through virtual scenarios (Killacky 2011:176). Formational education that takes a holistic purpose must also work towards the elusive realm of non-cognitive development, and this has been inadequately attended to in distance education research as well as in the traditional classroom (Saines 2009:341). Developing new perspectives and increasing self-awareness are part of the complex competency in theological formation. While there have been many efforts in developing taxonomies of affective learning (Anderson \& Krathwohl 2000), which is equated with formation, it has also been problematic to define, measure and assess (Cannel 2006:89; Overend 2007). There is agreement amongst educators that deep learning involves the affective domain and has to do with implicit values and beliefs (Le Cornu 2006:30; Saines 2009). In contrast, the 'surface approach' (Marton \& Säljö 1976) looks at external knowledge or information that is instrumentalist and can be memorised and regurgitated. The superficial learning leads to poor recall of the material learnt and the inability to apply the learning to different scenarios. Polanyi (1983) took a 'deep approach' looking past fixed knowledge to understand its meaning and significance, drawing links and connections wherever possible. A teaching space that is constructive and relational is critical for deep approaches to learning theology. At the same time, 'engagement with deep approaches to learning requires motivation and personal involvement' (Saines 2009:336). Le Cornu (2006) states that:

\footnotetext{
... this progression from surface to deep is primarily characterized by the degree to which meaning is sought and found, and can therefore be considered as a developing internalization through the process of reflection. (p. 12)
}

Polanyi speaks about 'tacit knowing', knowledge that 'is highly personal, embedded and difficult to formalize or codify' and links it to internalisation. At this final stage, 'external knowledge has been so absorbed into people's beings through the process of reflection that it is now part of them' (Le Cornu 2006:15).

What we find here is that instead of a constricted idea of 'ordered learning' as the product of learning only, attention must be given to the idea of education as a process, as the transformation of 'theological education will never be achieved through curriculum reform alone' (Hess 2005:89).
Relationships in the learning environment, the open teaching manner and extracurricular activities all shape the learning. The students now shift as consumers to producers of knowledge, a shift from the end product to the process. 'Preoccupation with content transmission obscures the important learning to be found in dialogue, debate, reflection on experience, and critical inquiry necessary for the development of wisdom' (Nysse 2011:14).

\section{Key pedagogical requirements for formation}

Formation is about engaging in intentional practices via structural processes and dynamics that shape and form students. It is about 'holding the institution accountable for its curricular objectives and the processes of formation' (Stache 2014:290). Academic staff will need to make the shift from contact pedagogical thinking to transformed pedagogy germane to the capacities of the distance environment. To do this, there are particular critical dimensions for formational education to happen successfully, conditions that must exist if formation is to happen. Because students are being formed as they participate, the dimensions of community, student support and faculty modelling are a necessity. This is because there is consensus in the literature revealing the communal aspect of formation (Graham 2003:60; Hines et al. 2009; Smith 2009:67). 'It relies on both interaction with others and the development of a supportive community' (Brown 2012:43). Of critical importance in the community is the work of mentoring and discipleship. The teacher is there to establish a community of learning and to be a mediator in that role. If these critical dimensions are not adhered to, then there will be no integration of appropriate interactive activities, no meaningful use of discussion forums, the possibility of creating a fake persona and the general lack of trust within the online community that can reduce the overall educational value. These factors will be explored in greater detail.

\section{Nurturing community}

Formational learning is understood as fundamentally relational and relies on a supportive environment so that interaction, internalisation and socialisation take place, and this is very much the case in the distance environment:

Thinking about community in a broader sense forces institutions to take into consideration not only the learning community of the institution but the community in which the student is located. (Stache 2014:288)

There is consensus that cyberspace is playing a decisive role in bringing together diverse people, bound not by geography but by shared interest. Pallof and Pratt (2007:25) state that technology has 'helped to create a new form of social interdependence enabling new communities to form wherever communication links can be made'. This is understood as the socio-emotional approach to learning (Brockbank \& McGill 1998:37). Students in this internetsavvy generation place a high value on relationships 
and community. They are naturally attracted to the combination of technology and the potential for learning in an online community. When there is engagement and participation, a sense of community naturally forms. 'This leads to social cohesion and authentic learning, leading again to stronger participation' (Wright 2011:58). Thriving learning communities involve 'social presence, authentic learning, and interdependency' (Shore 2007:88). 'Shared goals, trust and mutual support lead to quality social interaction which in turn leads to high performance' (Shea 2006:37).

Community can be developed when academic staff present material online in various formats, and discussion groups can serve to integrate the learning material. Hines et al. (2009) explain the process as:

\begin{abstract}
... weekly questions are posted to a discussion board, with each question targeting different aspects of learning, reflection, and application. Students post individual responses and reply to each other. The instructor facilitates ongoing asynchronous conversation until the end of the week. In threaded discussions, students are able to read each other's thoughts, carefully reflect on those thoughts and further the conversation. (p. 37)
\end{abstract}

This environment is often less threatening and encourages students to self-directed and to develop problem-solving skills (Wright 2011). The focus is on tacit knowledge that builds from constantly changing experiences, rather than fixed knowledge. These interactions between student and teacher, between students themselves, and between the student and the broader community make for formational learning as when dialogue is increased, transactional distance is reduced (Moore 1993). It 'develops and maintains relationships of mutuality and respect' (Graham 2003:60). These exchanges are central towards developing relationships as they show evidence of belonging and becoming.

Other hybrid models involve a combination of face-to-face and online learning opportunities (Delamarter \& Brunner 2005; Esselman 2005; Hege 2011:13; Maddix \& Estep 2010:76) known as the 'bricks and clicks' approach (Weigel Van 2002:60-126). This model starts with face-to-face contact and online communication continues the relationship. 'This model blends the best of traditional on-campus teaching and learning with online or technology-mediated resources, emphasising depth as well as access' (Naidoo 2012:6). Emphasis is on 'what learning objectives for the program need to be handled face-to-face and which can be done online' (Delamarter 2014:148).

\section{Student support}

One of the major challenges in providing formation in distance education is student support; the availability and provision of resources; technical help with the learning environment; and administrative and personal support (Graham 2002:228). Because there is a separation by distance, time and resources, there must be adequate student services and library resources. As Makoe (2006) states:
... students are expected to learn complex new material independently and to adjust to new ways of learning in this new environment. An initial lack of understanding of the academic world and its demands are often linked to an overall confusion about the nature and purpose of learning in higher education. (p. 365)

Constructive learning involves fitting into new knowledge with old understandings. Students at the beginning of learning are usually focused on the task and surface learning. As students grapple with 'new theological vocabulary, as their literacy and understandings develop so their deeper conceptual frameworks of meaning' (Saines 2009:339). Then students tend to move on to the personally enriching and communally engaged learning. A key factor is their increased motivation and engaging dialogue with peers and teachers. Students feel overwhelmed by the pressure of study alongside Christian ministry, especially when they do not have the basic building blocks of learning from their previous learning. Students are familiar with the conative (doing) and affective (feeling) and now have to focus on the cognitive (knowing) ways of learning. Without the required study and research skills and academic writing, students may not move on to deep learning.

Many students also express 'anxiety about their ability to master the technology, and they feared that their lack of expertise would jeopardize the learning of the subject'. This anxiety is aggravated by general infrastructure challenges in our context and institutions may have to provide learning centres and train students in the use of the computers or make computer laboratories available. Mabunda (2010:239) reminds us that the 'successful adoption of information and communication technologies needs to address different interlocking frameworks for change: infrastructure, attitude, staff development, support, sustainability and transferability'.

Formational distance education will need to deal with the ethical components as there could be instability caused from the growth in self-awareness. Patterson (1996) states that:

... education at its best moves the learner from one state of understanding to another, and that process will necessarily include times of disequilibrium. At such times, when the learner's emotional state is unsettled, and particularly when dealing with matters of faith, it is incumbent on the teacher to serve as monitor, guide and reassuring presence. The commitment of a theological faculty to educate must include a commitment to contain and to offer support in such disruption. (p. 62)

Online education will need clear principles to create a safe environment that can promote genuine dialogue:

It is important that process factors such as safety, emotional accessibility between members of the learning community, integrity and authenticity is established as core values or the structural factors will be only minimally effective. (Naidoo 2012:3) 
Pallof and Pratt (2007) also suggest that:

... understanding different culturally related beliefs about the nature of the individual and society may be critical in contributing to differing orientations towards self-expression and social interactions within educational settings. (p. 62)

Educators must be aware of students' context and how it impacts their learning. Clint, Graham and Mayes (2007:201) state that 'teaching to the student's context may be more important than focusing on a specific content in the distance arena'.

\section{Faculty as key to formation}

Faculty is the critical factor in the success of distance education. As formation education involves 'shifts in selfunderstanding, in adjusting world-views, in working out conflicting and possibly internally threatening or challenging information, this requires the presence and access to a supportive authority figure' (Ravoi, Baker \& Cox 2008:12). In this approach, the teacher shares his or her struggles to appropriate wisdom to the student as individualised mentoring becomes a value (Daloz 1987). 'The most meaningful experiences for students are focused on the teacher's relational skills and personal qualities, and in-class interactive teaching and learning methods' (Delamarter 2014:137). Hines et al. (2009) suggest that:

... assignments and class discussions become the primary field of learning, while lectures become supplementary and the teacher moves from the front of the room to assume a role as guide and mentor along a journey of explorative learning. (p. 36)

This change in role can be exciting and can be threatening. When teachers utilise learning theories built on interaction that enable formation, there should be evidence of this learning expressed by the students in their discursive interactions demonstrating membership in a community of practice (Wenger 1998) through aspects of belonging and becoming. The best instructional motivator and support for both cognitive and affective goals appear to be interaction with a teacher.

In the online mode, the 'competencies needed for teaching were identified as: content facilitator, technologist, designer, manager/administrator, process facilitator, adviser/counselor, assessor, and researcher' (Goodyear et al. 2001:69). 'Understanding the local context of the student, creating a learning community, and teaching information literacy have all been added to the professor's job description in an online course' (Goodyear et al. 2001:69). Thus, the teacher's role has expanded and therefore the approach to pedagogy must expand as well. However, as Delamarter (2005:148) states, 'theological education is not populated with faculty members with extensive backgrounds in educational methodology'. Those who are expected to use new methods should be well supported. Faculty members need training in the skills required to work with technology and need support for experimentation and innovation. In addition, teachers 'need better understanding of the paths and processes of adult development - of how persons develop identities, interact to create meaning and experience deep learning' (Weigel Van 2002:63).

\section{Conclusion}

With the growth in distance education and the change in the learning needs of students, attention needs to be made to providing formational education, but it must be based on sound pedagogy and the innovative use of instructional technology. It needs to prepare students for ministry in a world revolutionised by technology. Technology is no longer only in service of institutions; institutions also need technology to communicate effectively in the present day.

Nevertheless, it is also not helpful to naively believe that distance education and electronic media will always enhance the experience of students, but if academic staff can build capacity in formational education, the positives of accessibility, participation and flexibility can be used to craft a supportive learning environment. With the pedagogical focus of student centredness, learning in practice, holistic and transformative learning formational programmes can start to take shape.

\section{Acknowledgements Competing interests}

The author declares that she has no financial or personal relationship(s) that may have inappropriately influenced her in writing this article.

\section{References}

Anderson, L.W. \& Krathwohl, D.R. (eds.), 2000, A taxonomy for learning, teaching, and assessing: A revision of Bloom's taxonomy of educational objectives, Allyn \& Bacon, Boston, MA.

Ascough, R.S., 2002, 'Designing for online distance education: Putting pedagogy before technology', Teaching Theology and Religion 5(1), 17-29. https://doi.org/ 10.1111/1467-9647.00114

Bozkurt, A., Akgun-Ozbek, E., Yilmazel, S., Erdogdu, E., Ucar, H., Guler, E. et al., 2015, 'Trends in distance education research: A content analysis of journals 2009-2013', International Review of Research in Open and Distributed Learning 16(1), 330-363. https://doi.org/10.19173/irrodl.v16i1.1953

Brown, J.L.M., 2012, 'Online learning: A comparison of web-based and land-based courses', Quarterly Review of Distance Education 13(1), 39-49.

Brockbank, A. \& McGill, I., 1998, Facilitating reflective learning in higher education, The Society for Research into Higher Education, Buckingham.

Cannel, L., 2006, Theological education matters - Leadership education for the church, EDCOT Press, Newburgh, IN.

Clint, R.P., Graham, C.R. \& Mayes, C.T., 2007, 'Cultural competence and instructional design: Exploration research into the delivery of online instruction crossculturally', Educational Technology Research and Development 55(2), 197-217. https://doi.org/10.1007/s11423-007-9033-x

Cloete, A., 2015, 'Educational technologies: Exploring the ambiguous effect on the training of ministers', in M. Naidoo (ed.), Contested issues in training ministers in South Africa, pp. 141-154, Sun media, Stellenbosch.

Croft, S., 2008, 'Fresh expressions in a mixed economy Church: A perspective', in S Croft (ed.), Mission-shaped questions, pp. 1-15, Church House Publishing, London.

Daloz, L.A., 1987, Effective teaching and mentoring, Jossey-Bass, San Francisco, CA.

Dawson, L.L., 2004, 'Religion and the quest for virtual community', in L.L. Dawson \& D.E. Cowans (eds.), Religion online: Finding faith on the internet, pp. 75-91, Routledge, New York.

Delamarter, S., 2014, 'A typology of the use of technology in theological education', Teaching Theology and Religion 7(3), 134-140. https://doi.org/10.1111/j.14679647.2004.00203.x

Delamarter, S. \& Brunner, D.L., 2005, 'Theological education and hybrid models of distance learning', Theological Education 40(2), 145-164.

Elias, J.W., 2006, 'From a distance: Pastoral care and theological education', Teaching Theology \& Religion 9(1), 44-52. https://doi.org/10.1111/j.1467-9647.2006.00260.x 
Esselman, T., 2005, 'What technology can teach about theological pedagogy', in V.J. Klimoski, KJ.O. Neil \& K.M. Schuth (eds.), Educating leaders for ministry: Issues and responses, pp. 134-162, Liturgical Press, Collegeville, MN.

Goodyear, P., Salmon, G.J., Spector, M., Steeples, C. \& Tickner, S., 2001, 'Competences for online teaching: A special report', Educational Technology Research and Development 49(1), 65-72. https://doi.org/10.1007/BF02504508

Graham, S.L., 2002, 'Theological education on the web: A case study in formation for ministry', Teaching Theology and Religion 5(4), 227-235. https://doi.org/ 10.1111/1467-9647.00142

Graham, S.L., 2003, 'Instructional design for affective learning in theological education', British Journal of Theological Education 14(1), 58-77.

Hefner, P., 2003, Technology and human becoming, Fortress Press, Minneapolis, MN.

Hege, B.A.R., 2011, 'The online theology classroom: Strategies for engaging a community of distance learners in a hybrid model of online education', Teaching Theology and Religion 14(1), 13-20. https://doi.org/10.1111/j.1467-9647.2010. 00668.x

Hess, M., 2005, 'Engaging technology in theological education: All that we cannot leave behind, Rowan \& Littlefield, Lanham, MD.

Hess, M., 2013, 'A new culture of learning: Implications of digital culture for communities of faith', Communication Research Trends 32(3), 3-13.

Hines, T.S., Macgee, T.R., Waller, L. \& Waller, S.K., 2009, 'Online theological education: A case study of Trinity School for Ministry', Christian Higher Education 8, 32-41. https://doi.org/10.1080/15363750802201284

Killacky, C., 2011, 'Developing a useful teaching delivery selection model for theological seminaries using technology as a medium', Journal for Adult Theological Education 8(2), 166-185. https://doi.org/10.1558/JATE.v8i2.166

Le Cornu, A., 2006, 'Theological reflection and Christian formation', The Journal of Adult Theological Education 3(1), 11-36. https://doi.org/10.1558/jate.2006.3.1.11

Lowe, S.D. \& Lowe, M.E., 2010, 'Spiritual formation in theological distance education: An ecosystems model', Christian Education Journal 7(1), 85-102. https://doi. org/10.1177/073989131000700106

Mabunda, P.L., 2010, 'Information and communication technologies for teaching and learning: Challenges and implications for ODL universities', Progressio 32(2), 222-244

Maddix, M.A. \& Estep, J.R., 2010, 'Spiritual formation in online higher education communities: Nurturing spirituality in Christian higher education online degree
programs', Christian Education Journal 7(2), 423-434. https://doi.org/10.1177/ programs', Christian Ed
073989131000700212

Makoe, M.Q., 2006, 'South African distance students' accounts of learning in sociocultural context: A habitus analysis', Race, Ethnicity and Education 9(4), 361-380. cultural context: A habitus analysis', Race, Ethnicit
https://doi.org/10.1080/13613320600957678

Martin, B. \& Briggs, L., 1986, The affective and cognitive domains: Integration for instruction and research, Education Technology, Engelwood Cliffs, NJ.

Marton, F. \& R. Säljö., 1976, 'On qualitative differences in learning: I - Outcome and process; II-Outcome as a function of the learner's conception of the task', British Journal of Educational Psychology 46, 115-127. https://doi.org/10.1111/j.20448279.1976.tb02304.x

Mezirow, J., 1990, Fostering critical reflection in adulthood, Jossey-Bass, San Francisco, CA.

Moore, M.G., 1993, 'Theory of transactional distance', in D. Keegan (ed.), Theoretical principles of distance education, pp. 22-38, Routledge, New York.

Moodie, T., 2008, 'TEE College of Southern Africa', in R. Kinsler (ed.), Diversified theological education: Equipping all God's people, pp. 47-80, William Carey International University, Pasadena.
Naidoo, M., 2011, 'An empirical study on spiritual formation at theological training institutions in South Africa', Religion and Theology 18(4), 118-146. https://doi. institutions in South Africa', Religion
org/10.1163/157430111X613692

Naidoo, M., 2012, 'Ministerial formation of theological students through distance education', HTS Teologiese Studies/ Theological Studies 68(2), 1-8. https://doi. org/10.4102/hts.v68i2.1225

Njenga, J.K. \& Fourie, L.C.H., 2010, 'The myths about e-learning in higher education', British Journal of Educational Technology 41(2), 199-212. https://doi.org/ 10.1111/j.1467-8535.2008.00910.x

Nysse, R., 2011, 'Learning from "digital natives": Forming a new generation of religious leaders', Reflective Practice: Formation and Supervision in Ministry 31, 11-19.

Overend, P., 2007, 'Education or formation: The issue of personhood in learning for ministry', Journal of Adult Theological Education 4(2), 133-148. https://doi. org/10.1558/jate2007v4i2.133

Pallof, R.M. \& Pratt, K., 2007, Building on-line learning communities: Effective strategies for the virtual classroom, Jossey Bass, San Francisco, CA.

Patterson, E., 1996, 'The questions of distance education', Theological Education 33(1), 59-74.

Paulsell, S., 2011, 'Technology and ministry', Reflective Practice: Formation and Supervision in Ministry 31, 20-34.

Pelz, B., 2004, 'Three principles of effective online pedagogy', Journal of Asynchronous Learning Networks 14(1), 12-24.

Polanyi, M., 1983, The tacit dimension, Peter Smith, Gloucester, MA.

Ravoi, A.P., Baker, J.D. \& Cox, W.F., 2008, 'How Christianly is Christian distance higher education?', Christian Higher Education 7, 1-22. https://doi.org/10.1080/ 15363750701285941

Ravoi, A.P. \& Jordan, H.M., 2004, 'Blended learning and sense of community: A comparative analysis with traditional and fully online graduate courses', International Review of Research in Open and Distance Learning 5(2), 471-489.

Reissner, A., 1999, 'An examination of formational and transformational issue in conducting distance learning', Theological Education 36(1), 87-100.

Russel, T.L., 1999, The no significance difference phenomenon, North Carolina State University, Raleigh, NC.

Saines, D., 2009, 'How do students learn theology?', Teaching Theology and Religion 12(4), 333-347. https://doi.org/10.1111/j.1467-9647.2009.00547.x

Shea, P., 2006, 'A study of student's sense of learning community in online environments', Journal of Asynchronous Learning Networks 10(1), 35-44.

Shore, M.H., 2007, 'Establishing social presence in online courses: Why and how', Theological Education 42(2), 91-100.

Smith, J.K.A., 2009, Desiring the kingdom: Worship, worldview and cultural formation, Baker Academic, Grand Rapids, MI.

Stache, K., 2014, 'Formation for the whole church: A new/old vision of theological education in the 21st century', Dialoog 53(4), 286-292. https://doi.org/10.1111/ dial.12129

Weigel Van, B., 2002, Deep learning for a digital age: Technology's untapped potential to enrich higher education, Jossey-Bass, San Francisco, CA.

Weinski, M.C., 2008, 'Understanding and promoting life change among evangelical theological students in Germany', Common Ground Journal 5(2), 107-119.

Wenger, E., 1998, Communities of practice: Learning, meaning, and identity, Cambridge University Press, Cambridge.

Wright, S., 2011, 'Excellence in e-learning: E-learning to enhance learning and community', Journal of Christian Education 54(1), 57-67. https://doi.org/10.1177/ 002196571105400106 